STUDIA POLONIJNE

T. 41. LUBLIN 2020

DOI: http://doi.org/10.18290/sp2041-8

JÓZEF SZYMAŃSKI

\title{
PARAFIA NSPJ W NEW BRITAIN I JEJ DUSZPASTERZE NA ŁAMACH „DZIENNIKA CHICAGOSKIEGO” W LATACH 1894-1920
}

Miasto New Britain leży w powiecie Hartford, w centrum Stanu Connecticut, kilkanaście mil na północ od Meriden. W 1913 r. było zamieszkałe przez 40 tysięcy osób ${ }^{1}$ różnych narodowości, wśród których dominowali Polacy ${ }^{2}$, potem Niemcy, Włosi, Szwedzi, Litwini i Rusini. Spośród mieszkańców tego miasta Polacy, Szwedzi i Rusini posiadali swoje pisma tygodniowe. Polacy przed Bożym Narodzeniem 1907 r. wydali pierwszy numer „Przewodnika Katolickiego”’. W ten sposób scharakteryzował mieszkańców miasta korespondent „Dziennika Chicagoskiego”:

Wszystkie liczniejsze narodowości ${ }^{4}$ osiedliły się we właściwych sobie dzielnicach, ułatwiając przez to wszelką akcję organizowania się, porozumień i wspólnej pracy.

Ks. dr hab. JózeF SzYMAŃski, prof. AP - Instytut Historii na Akademii Pomorskiej w Słupsku; e-mail: jozef.szymanski@apsl.edu.pl. ORCID: https://orcid.org/0000-0003-3799-200X.

${ }^{1}$ (Od naszego specyalnego podróżujacego korespondenta.) Korespondencye ze Wschodu, New Britain, Conn., „Dziennik Chicagoski” nr 90, 17 kwietnia 1913, s. 5.

2 Z New Britain, Conn., „Dziennik Chicagoski” nr 240, 13 października 1922, s. 3.

3 Notatki, „Dziennik Chicagoski” nr 42, 19 lutego 1908, s. 4. [Przewodnik Katolicki] „Pismo to wychodzi w New Britain, Conn., a wydaje je ks. Lucyan Bójnowski za aprobatą biskupią. Pismo to stosunkowo jest tanie. Numer zawiera 32 strony druku; wydawane co tygodnia, pismo kosztuje tylko rocznie \$2.00. Treść bogata. Przeważają artykuły religijnej treści, ale nie brak tam także pouczających artykułów o kwestiach społecznych, wiadomości ze świata, z kraju tutejszego, z naszej Ojczyzny, ż życia Polaków w Ameryce i rozmaitości mogących każdego zainteresować”; Która gazeta jest dobra w Ameryce? „Dziennik Chicagoski” nr 39, 16 lutego 1909, s. 3. „Jest to gazeta tygodniowa, religijno-społeczna, która roznieca w ludziach wiarę i miłość, prowadzi do prawdziwej oświaty i moralności. Obfituje w nowiny najrozmaitsze, ciekawe rzeczy itp. W każdym więc domu, w każdej rodzinie powinna być ta gazeta na stole i w ręku, bo oprócz szerzenia wiary i oświaty prawdziwej, czysty dochód z gazety jest przeznaczony na utrzymanie sierot w ochronce polskiej w New Britain, Conn.”; R. NIR, Szkice z dziejów Polonii, Orchard Lake, Michigan 1990, s. 334. „Przed Bożym Narodzeniem 1907 r. wydany został pierwszy numer „Przewodnika Katolickiego”. Mała drukarnia znajdowała się wówczas pod plebanią”; ks. B. Kumor, Kościelne dzieje Polonii w Connecticut 1870-1986, „Nasza Przeszłość” 73(1990), s. 230.

${ }^{4}$ Cytaty z zachowaniem składni, ortografii i stylu. 
Jedynie Żydzi, wdzierający się w rozmaite możliwe i niemożliwe gałęzie handlu i przemysłu, rozsypali się po wszystkich dzielnicach i starali się swoim wrodzonym sprytem wyzyskać „obcych” dla swoich celów finansowych. Operacji tej najwięcej podlegali Polacy ${ }^{5}$.

Znaczący napływ imigrantów do tego miasta na łamach ,Dziennika Chicagoskiego" uzasadniano zapotrzebowaniem na pracowników na lokalnym rynku pracy. Miejscowe fabryki chętnie przyjmowały do pracy wszystkich przybyszów. Najwięcej Polaków pracowało w fabrykach: Corbin Screw Corporation i Stanley Works.

Polacy w tym mieście, w znacznej liczbie byli właścicielami domów. Było również kilku zamożniejszych sklepikarzy, (Cieszyński, który miał sklep z meblami i Skrentny, sklep rozmaitości). Była spółka - piekarnia polska i kilka innych małych przedsiębiorstw. Handel polski, w stosunku do liczby Polaków, nie był dostatecznie rozwinięty. Ludność polska w New Britain z małymi wyjątkami, nie rozumiała istotnej i opłacającej się gałęzi pracy w Ameryce. Fabryki były jedynymi miejscami pracy, dzięki którym Polacy mogli się utrzymać; poza nimi nie łatwo dostrzegano inne możliwości podjęcia pracy zarobkowej, głównie korzystniejszej dla siebie, a przy tym i dla swoich rodaków ${ }^{6}$.

Mieszkańcy New Britain: Polacy, Niemcy, Litwini i Rusini wybudowali dla zaspokajania swoich potrzeb religijnych po jednej świątyni katolickiej, Irlandczycy dwie ${ }^{7}$. Diaspora polska w tym mieście liczyła wówczas prawie siedem tysięcy osób. Sama polska parafia liczyła o pół tysiąca wiernych więcej, ponieważ należało do niej wielu Polaków z sąsiednich miejscowości, w których nie było polskich świątyń ${ }^{8}$. Gazeta wprost informowała na swoich łamach o napływie do miasta kolejnych emigrantów z ziem polskich: „Polacy z pod zaboru rosyjskiego dziesiątkami przybywają do New Britain. W ubiegłym tygodniu pomiędzy 24-tym a 31-szym maja przybyło tu pięćdziesięciu imigrantów polskich płci obojej. Niezadługo - New Britain stanie się miastem polskim"”. Pierwszym Polakiem, który osiedlił się w New Britain, był Tomasz Ostrowski. 29 stycznia 1889 r. Polacy zamieszkujący miasto, wspólnie podjęli decyzję o założeniu Towarzystwa Wzajemnej Pomocy pw. św. Michała, które z kolei wyszło z inicjatywą założenia polskiej

5 (Od naszego specyalnego podróżującego korespondenta.) Korespondencye ze Wschodu, New Britain, Conn., „Dziennik Chicagoski” nr 90, 17 kwietnia 1913, s. 5.

${ }^{6}$ Polacy w New Britain, „Dziennik Chicagoski” nr 90, 17 kwietnia 1913, s. 5.

${ }^{7}$ (Od naszego specyalnego podróżującego korespondenta.) Korespondencye ze Wschodu, New Britain, Conn., „Dziennik Chicagoski” nr 90, 17 kwietnia 1913, s. 5.

${ }^{8}$ Polacy w New Britain, „Dziennik Chicagoski” nr 90, 17 kwietnia 1913, s. 5.

9 Z New Britain, Conn., „Dziennik Chicagoski” nr 240, 8 października 1913, s. 3. 
parafii pw. św. Kazimierza w tym mieście. Zawiązane w tym celu stowarzyszenie parafialne, ukonstytuowane 14 listopada 1894 r. przez rząd stanowy, od strony formalnej zajęło się wraz z ks. dr. Tomaszem Misickim ${ }^{10}$ jej organizacją ${ }^{11}$. Towarzystwo to wzięło na siebie główny ciężar starań o utworzenie parafii. Gromadziło pierwsze fundusze, dokonywało spisu ludności polskiej, zakupywało odpowiednie działki ziemi, budynki, a nade wszystko zabiegało o pozwolenie na założenie parafii $^{12}$. O wynikach podjętych przez wiernych wspólnie z proboszczem działań można było przeczytać w „Dzienniku Chicagoskim”: „W New Britain, Conn. Wiel. ks. dr Misicki zakłada nową parafię polską"13. Kapłan ten od czerwca 1894 r. dojeżdżał z Meriden ${ }^{14}$, Conn., gdzie był proboszczem w każdą niedzielę i święta z posługą duszpasterską, do wynajętego od Irlandczyków kościoła NMP w New Britain ${ }^{15}$. W ten sposób wspólnotę scharakteryzował ks. W. Kruszka: „Przy założeniu parafii było blisko 700 głów, zaś r. 1900. parafia liczyła z górą z dziećmi 1,700 głów. [...] Parafia składa się z Polaków przeważnie z Kongresówki (cztery siódme), z Galicyi

${ }^{10}$ Urodził się 31 grudnia 1866 r. w Przeworsku. Tamże ukończył szkołę podstawową, małe seminarium u Księży Misjonarzy w Krakowie i (1888) gimnazjum Sobieskiego w Krakowie. Studiował na Uniwersytecie Jagiellońskim teologię i filozofię (1890-1892). Tamże, 1 lutego 1892 r. na Wydziale Teologii uzyskał doktorat, a na Wydziale Filozofii absolutorium pozwalające nauczać języków klasycznych w gimnazjum. 19 maja 1892 r. przyjął święcenia kapłańskie. W tymże roku udał się do Ameryki Północnej. Z początkiem marca, jako wikariusz podjął posługę duszpasterską w parafii polskiej św. Stanisława w Winonie, Minn., gdzie starał się o założenie Wyższej Szkoły Polskiej. Później pełnił posługę duszpasterską m.in. jako proboszcz w Meriden, Conn. (1893-1896), następnie w Mt. Carmel Phila. Od połowy grudnia 1900 r. do 21 stycznia 1901 r. był administratorem parafii św. Jozafata w Manayunk, Pa. Od 1916 r. był proboszczem w parafii MB Różańcowej. Zmarł 31 października 1935 r. w Williamsport (Pensylwania). R. NIR, Misicki Tomasz, w: Encyklopedia polskiej emigracji i Polonii, red. K. Dopierała, t. III, Toruń 2004, s. 323-324; W parafii polskiej św. Stanisława w Winonie, Minn., „Dziennik Chicagoski” nr 59, 10 marca 1893, s. 1; Polacy w Ameryce, „Dziennik Chicagoski” nr 103, 3 maja 1893, s. 2; Historia polskich rzymsko-katolickich parafij archidiecezji filadelfijskiej w Stanach Zjednoczonych Pótnocnej Ameryki, Philadelphiae 1938, s. 62, 209; ks. B. KUMOR, Kościelne dzieje Polonii w Connecticut, s. 236, 256.

${ }^{11}$ Ks. L. BóJNowski, Historja parafji polskich $w$ diecezji hartfordskiej $w$ Stanie Connecticut w Stanach Zjednoczonych, New Britain, Conn., 1939, s. 27; ks. B. Kumor, Z problemów ludnościowych polskiej parafii Najśw. Serca Jezusowego w New Britan, Conn. (1895-1920), „Studia Polonijne” 5(1982), s. 261-262.

12 Ks. B. Kumor, Kościelne dzieje Polonii w Connecticut, s. 219-222.

13 Polacy w Ameryce. W New Britain, Conn., „Dziennik Chicagoski” nr 229, 3 października 1894, s. 4.

${ }^{14}$ Ks. J. SzYMański, Parafia w Meriden i jej duszpasterze na łamach „Dziennika Chicagoskiego” w latach 1893-1920, „Archiwa, Biblioteki i Muzea Kościelne” 114 (2020) [w druku].

${ }^{15}$ Ks. L. Bójnowski, Historja parafji polskich $w$ diecezji hartfordskiej, s. 27; ks. B. Kumor, Z problemów ludnościowych polskiej parafii Najśw. Serca Jezusowego w New Britan, s. 262. 
dwie siódme, z Poznańskiego 1 siódma. Wszystkich familii polskich roku 1902. było około 300, kawalerów blisko 700, panien z górą 359, dzieci blisko 500"16.

Przy organizowaniu parafii w New Britain, na skutek braku akceptacji dla lokalizacji budowy kościoła przez część wiernych doszło do nieporozumień. Utworzyły się dwa stronnictwa, po przeciwległych stronach miasta. W lipcu 1895 r. powstał kościół niezależny ${ }^{17}$, nie przejawiał on jednak większej aktywności. O swoim istnieniu jego działacze próbowali jeszcze przypomnieć społeczności New Britain wielokrotnie ${ }^{18}$. W tym samym czasie, 10 września obowiązki proboszcza parafii przejął ks. Lucjan Bójnowski ${ }^{19}$, dotychczasowy wikariusz ks. T. Misickiego w Meriden. 14 października wierni wraz z proboszczem zdecydowali o zakupie nowego placu pod budowę świątyni przy ul. Orange i budowie kościoła pw. Najświętszego Serca Jezusowego. Solidarnie realizowane przez proboszcza i wiernych przedsięwzięcie zostało urzeczywistnione już 19 lipca 1896 r. poprzez poświęcenie nowo wybudowanej drewnianej świątyni. W celu utrzymania parafii i kontynuowania prac przy kościele organizowano loterię, z której dochód wynosił $\$ 263.10^{20}$. Działania te w tym celu wielokrotnie ponawiano ${ }^{21}$. Charakteryzując w $1902 \mathrm{r}$. społeczność polską zamieszkującą $\mathrm{w}$ tym stanie, korespondent gazety napisał: „W stanie Connecticut od 6 do 7 tysięcy Polaków, oprócz Litwinów, których bardzo często zaliczają do Polaków. Polskich parafii w Stanie Connecticut jest obecnie 5, a mianowicie: W Hartford, New Britain, Bridgeport, Meriden i w New Haven. Najlepiej z nich uposażona jest parafia w New Britain, której majątek nieruchomy

${ }^{16}$ W. KruszKa, Historya polska w Ameryce. Początek, wzrost i rozwój dziejowy osad polskich w Pólnocnej Ameryce (w Stanach Zjednoczonych i Kanadzie), t. 13, Milwaukee, Wis., 1908, s. 66.

${ }^{17} O$,,niezależnym” Kamińskim, „Dziennik Chicagoski” nr 245, 21 października 1895, s. 2; W. KruszKa, Historya polska w Ameryce, t. 13, s. 65. „Ci sami niezależni próbowali wedrzeć się do New Britain zaraz po zorganizowaniu parafii polskiej w roku 1895. Posiadali wtedy swoje grunta przy Church ulicy, o które ks. L. Bójnowski przez trzy lata przed sądem dochodził praw wspólnoty parafialnej”. Ks. L. BóJNOwski, Historja parafji polskich w diecezji hartfordskiej, s. 27-30.

${ }^{18}$ Polacy w New Britain, „Dziennik Chicagoski” nr 90, 17 kwietnia 1913, s. 5.

${ }^{19}$ Urodził się 5 lutego 1868 r. w Świerzbutowie, k. Sokółki, w guberni grodzieńskiej. W 1888 r. przybył do Stanów Zjednoczonych. W następnym roku podjął studia filozoficzno-teologiczne w seminarium polskim w Detroit, Mich. 20 stycznia 1895 r. z rąk bpa M. Tierneya przyjął święcenia kapłańskie. 27 stycznia 1895 r. został wikariuszem w Meriden. Od 30 maja zastępował proboszcza w słowackiej parafii pw. św. Jana Nepomucena w Bridgeport. 10 września 1895 r. został proboszczem w parafii NSPJ w New Britain, gdzie przez 62 lata pełnił ten urząd. Zmarł 28 lipca 1960 r. Ks. L. BóJNOwsKi, Historja parafji polskich w diecezji hartfordskiej, s. 27-30; ks. B. KuMOR, Z problemów ludnościowych polskiej parafii Najśw. Serca Jezusowego w New Britan, s. 262; R. NIR, Szkice z dziejów Polonii, s. 332-336.

${ }^{20}$ Fair w New Britain Conn., „Dziennik Chicagoski” nr 283, 10 grudnia 1897, s. 2.

${ }^{21}$ Z New Britain Conn., „Dziennik Chicagoski” nr 272, 20 października 1899, s. 4. 
przedstawia dziesiątki tysięcy dolarów"22. O zamożności parafii świadczył fakt, że ks. L. Bójnowski wraz z wiernymi, pięć lat później podjął się budowy nowej, murowanej świątyni. O czym i tym razem poinformowano na łamach dziennika: „22 sierpnia 1902 r. Polacy w New Britain, Conn., budują nowy kamienny kościół, który będzie kosztować \$85,000". Tym samym apelowano do czytelników - mieszkańców miasta, o wsparcie dla podjętego przedsięwzięcia ${ }^{23}$.

Przychody materialne wspólnoty parafialnej pozwoliły proboszczowi i wiernym, pomimo realizowanej budowy nowego kościoła, 15 września 1904 r. na założenie ochronki polskiej dla sierot ${ }^{24}$. Na początku nowa placówka przyjęła pod swój dach blisko 50 dzieci $^{25}$. „Śmierć matki, która pozostawiła kilka dzieci, oraz brak rodziny, która wyraziłaby chęć wychowywania sierot, stały się natchnieniem dla proboszcza parafii. Postanowił założyć polską ochronkę, w której dzieci sieroty znajdą przytułek i dobre wychowanie, gdzie nie stracą ani wiary ani mowy ojczystej”26. Poświęcenie polskiego sierocińca miało miejsce 30 maja 1906 r. $^{27}$

22 Polacy w Ameryce. Z Hartford, Conn., „Dziennik Chicagoski” nr 236, 6 października 1902, s. 4.

${ }^{23}$ Z New Britain Conn., „Dziennik Chicagoski” nr 200, 27 sierpnia 1902, s. 4. „New Britain, Conn., d. 22 sierpnia 1902 r. Polacy w New Britain, Conn., budują nowy kamienny kościół, który będzie kosztować $\$ 85,000$, i z tej przyczyny parafia urządza na dochód kościoła fantową loteryę czyli «fair», aby przez to przyczynić się choć trochę do budowy świątyni pańskiej. Fantowa loterya czyli «fair» 14 rozpocznie się d. 30go sierpnia, o godz., 7ej wiecz. i będzie trwać cały tydzień, to jest do dnia 7go września; przez cały ten przeciąg czasu «fair» 41 będzie się rozpoczynać każdego wieczora o godz. 7ej”.

${ }^{24}$ Prośba do Szanownego Społeczeństwa, „Dziennik Chicagoski” nr 298, 21 listopada 1922, s. 7. „Przez 18 lat swego istnienia do zakładu przyjęto chłopców i dziewcząt 600. Umarło chłopców i dziewcząt 92, poszło w świat i zarabia na swoje utrzymanie chłopców i dziewcząt 403, w zakładzie jest chłopców i dziewcząt 105. Na zakupienie gruntu pod ochronkę i na utrzymanie tych sierot wydano dotychczas $\$ 260,835.92$. Dotychczas za utrzymanie sierot zakład otrzymał od krewnych zapłaty $\$ 22,913.94 ”$

${ }^{25}$ Ks. L. BóJnowski, Sprawozdanie z Ochronki Polskiej w New Britain Conn., „Dziennik Chicagoski” nr 51, 6 marca 1906, s. 2. Zakład głównie utrzymywał się z ofiarności duchowieństwa i wiernych, z tego względu przedstawiono sprawozdanie roczne, które egzemplifikuje koszty utrzymania zakładu: „Dochody od 1 stycznia do 31 grudnia 1905 roku. Zapłata za dzieci \$448.00. Ofiary od osób $\$ 3,762.47$ Ofiary Towarzystw $\$ 152.55$. Z przedstawienia $\$ 106.10$. Za opłatki 65.42. Gwiazdka 336.29. Razem $\$ 4,870.83$. Rozchody. Sprzęty domowe $\$ 375.75$. Ubranie $\$ 1,074.84$. Wiktuały spożywcze 1,601.61. Drzewo i węgle 291.46. Książki 194.36. Pościel 125.19 Remont domu 650.00. Podróże 91.36. Nauka (za granie itd.) 149.25. Ubezpieczenie od ognia 10.00. Doktór i lekarstwo 476.10. Budowa ochronki nowej 461. Oświetlanie domu 89.23. Woda 12.15. Lód - 17.96. Obrazki i druki 104.40. Razem \$591.47. Zestawienie; Rozchodu \$5,901.47. Dochodu \$4.870.83. Zatem pozostało do zapłacenia 1.030.64. Dzieci w obecnej chwili w ochronce jest: chłopców 20, dziewcząt 27, na 1 kwietnia ma być przyjętych: chłopców 5, dziewcząt 6 , razem 58. Sierot obsługuje 20 sióstr. Z powyższego sprawozdania okazuje się, że zakład ma jeszcze do zapłacenia $\$ 1,030.64$ ".

${ }^{26}$ R. NIR, Szkice z dziejów Polonii, s. 333.

${ }^{27}$ Ks. L. Bójnowski, Poświęcenie Ochronki Polskiej w New Britain, Conn., „Dziennik Chicagoski" nr 119, 26 maja 1906, s. 3. 
Prowadzenie ochronki ks. Bójnowski powierzył Zgromadzeniu Sióstr Matki Boskiej Różanostockiej, których zadaniem było pielęgnowanie sierot i wykonywanie możliwej dla kobiet pracy na roli, którą założyciel zakupił dla sierot ${ }^{28}$. Zgromadzenie ${ }^{29}$ liczyło ponad 40 sióstr. Z myślą o zebraniu środków na utrzymanie sierocińca zarówno ks. proboszcz, jak i siostry apelowali do czytelników gazety o wsparcie materialne i organizowali koncerty ${ }^{30}$. W $1911 \mathrm{r}$. sytuacja materialna parafii umożliwiła ks. L. Bójnowskiemu zakupienie działki pod budowę nowego sierocińca $^{31}$. Przez 17 lat prowadzonej działalności opiekuńczej, ochronka przyjęła łącznie 560 chłopców i dziewcząt. Z uwagi na ograniczone możliwości lokalowe w przyjmowaniu dzieci do ochronki (przyjmowano wówczas co dziesiątą sierotę), ks. Bójnowski dziesięć lat później zdecydował o budowie nowego sierocińca z 300 miejscami ${ }^{32}$. O owym przedsięwzięciu również poinformowano na łamach dziennika: „W New Britain, Conn. miejscowy proboszcz ks. Bójnowski rozpoczął kolektę na budowę nowego murowanego gmachu na pomieszczenie sierocińca. Sierociniec mieści się w dwóch oddzielnych domach. Proboszcz ma zamiar zbudować jeden olbrzymi gmach, w którym możnaby pomieścić wszystkie sierotki. Domy, w których się obecnie mieszczą sieroty, będą sprzedane" ${ }^{33}$. Ponadto, celem zapewnienia środków na utrzymanie ochronki ks. proboszcz wydawał gazetę polską - „Przewodnik Katolicki”34. W 1921 r. wszelkie prawa z wydawaniem pisma przeszły na spółkę wydawniczą „Księgarnia i Drukarnia św. Wojciecha w Poznaniu”35.

Edukacja dzieci i dorastającej młodzieży polskiej w New Britain była kolejnym, równie ważnym wyzwaniem dla parafii i jej duszpasterza. Młodzi ludzie wchodzili w dorosłe życie bez praktyki, nauki i oświaty. Szkoła publiczna stanowiła duże nie-

${ }^{28}$ Polacy w New Britain, „Dziennik Chicagoski” nr 90, 17 kwietnia 1913, s. 5; Ks. L. BóJnowSKI, Historja parafji polskich $w$ diecezji hartfordskiej, s. 124-132, 296-297; R. NIR, Szkice z dziejów Polonii, s. 333-334.

${ }^{29}$ W. KruszKa, Historya polska w Ameryce, t. 13, s. 66. Zdaniem ks. Kruszki opiekę nad ochronką objęły polskie ss. bernardynki z Krakowa, 21 października 1906 r., co jest twierdzeniem błędnym.

${ }^{30}$ Z New Britain, Conn., „Dziennik Chicagoski” nr 32, 7 lutego 1907, s. 5.

31 W New Britain, Conn., „Dziennik Chicagoski” nr 271, 22 listopada 1911, s. 5. „Wiel. ks. L. Bójnowski zakupił wielki obszar ziemi na Osgood ave., od Andrzeja Semanika, pod nowy sierociniec, który rozpoczną budować w następnym miesiącu".

32 Prośba do Szanownego Społeczeństwa, „Dziennik Chicagoski” nr 82, 7 kwietnia 1922, s. 5.

33 W New Britain, Conn., „Dziennik Chicagoski” nr 67, 21 marca 1911, s. 8.

${ }^{34}$ Zob. przyp. 3.

${ }^{35}$ Z naszej prasy: „,Przewodnik Katolicki”, „Dziennik Chicagoski” nr 180, 3 sierpnia 1921, s. 4. Przedstawicielem Księgarni i Drukarni św. Wojciecha na Amerykę, a zarazem przełożonym oddziału tej organizacji i redaktorem „Przewodnika Katolickiego” został ks. S. Iciek, jego pomocnikiem ks. J. Taranowicz. (Był wikariuszem ks. Bójnowskiego w New Britain, od 2 stycznia 1921 r. do 1 maja 1922 r.); R. NiR, Szkice z dziejów Polonii, s. 335. 
bezpieczeństwo szybszej amerykanizacji. Stąd, z myślą o przyszłości polskich dzieci, w 1896 r. proboszcz zorganizował szkołę polską, w której lekcje prowadzili: Wieńczysław Woroniecki, dr Karol Laskowski i Leon Bójnowski dla 40 dzieci $^{36}$. W następnym roku do szkoły uczęszczało 50 dzieci $^{37}$, a w 1902 r. $-150^{38}$. W roku 1906 dla około 500 dzieci lekcje prowadziło siedmiu nauczycieli świeckich. W 1909 r. do szkoły parafialnej polskiej uczęszczało 1015 dzieci, z tej liczby kilkadziesiąt uczniów rok rocznie wychodziło z dyplomami ${ }^{39}$. Większość absolwentów po ukończeniu szkoły podejmowała pracę w fabryce. Ze względu na niezwykle wysoki wówczas przyrost naturalny Polonii, szkoła nie była w stanie pomieścić swych uczniów. Proboszcz zdecydował więc o budowie nowoczesnej, obszernej szkoły ${ }^{40}$. Jeszcze w lipcu $1910 \mathrm{r}$. poszukiwano dla niej nauczycielek ${ }^{41} .10$ września 1910 r. miało miejsce poświęcenie nowego obiektu szkolnego. Wydarzenie to umożliwiło ks. arcybiskupowi J. Weberowi zapoznanie się z funkcjonowaniem szkoły, ochronki dla dziewcząt i chłopców, a po nieszporach nawiedzenie miejscowego cmentarza $^{42}$, oraz gospodarstwa należącego do ochronki polskiej i drukarni „Przewodnika Katolickiego"43. Wybudowanie nowej szkoły nie rozwiązało jednak wspomnianego problemu. W 1913 r. szkoła w dalszym ciągu nie mogła pomieścić wszystkich dzieci, oddano więc do użytku stare klasy w budynku plebanii. Dzieci szkolne pozostały pod kontrolą nauczycieli i nauczycielek świeckich oraz kilku sióstr ze Zgromadzenia Matki Boskiej Różanostockiej. W gronie nauczycieli szkoły polskiej były trzy nauczycielki angielskie ${ }^{44}$.

Księdzu proboszczowi Lucjanowi Bójnowskiemu w posłudze duszpasterskiej w New Britain pomagali kolejno następujący kapłani ${ }^{45}$ : od 20 czerwca do 30 września

${ }^{36}$ Ks. B. Kumor, Kościelne dzieje Polonii w Connecticut, s. 273-274; W. Kruszka, Historya polska w Ameryce, t. 13, s. 66.

${ }^{37}$ Ks. L. BóJnowski, Z New Britain Conn., „Dziennik Chicagoski” nr 33, 9 lutego 1897, s. 2.

${ }^{38}$ W. KruszKa, Historya polska w Ameryce, t. 13, s. 66.

39 Szkoła polska w New Britain Conn., „Dziennik Chicagoski” nr 114, 15 maja 1909, s. 4.

${ }^{40}$ Ks. B. Kumor, Kościelne dzieje Polonii w Connecticut, s. 275.

${ }^{41}$ Potrzeba nauczycielek do szkoły polskiej, „Dziennik Chicagoski” nr 175, 29 lipca 1910, s. 7. „Nauczycielki, które posiadają amerykański «Teachers Certificate» i posiadają gruntowną znajomość języka polskiego, niech natychmiast podadzą swoje warunki i listownie niech się zgłoszą do: Ks. L. Bójnowski, Orange ulica, New Britaln, Conn."

42 Z New Britain, Conn., „Dziennik Chicagoski” nr 34, 9 lutego 1912, s. 6. W 1912 r. założony został cmentarz polski. Miejscowa ludność polska na urządzenie tego cmentarza złożyła na ręce proboszcza ks. Bójnowskiego ofiary: Towarzystwo Rycerzy Bolesława Chrobrego ofiarowało na ten cel 500 dol., Towarzystwo Pań - 50 dol. i Towarzystwo Młodzieży Polskiej Katolickiej - 75 dol.

${ }^{43}$ Poświęcenie szkoły polskiej N. Serca Jezusowego, w New Britain, Conn., „Dziennik Chicagoski” nr 212, 13 września 1910, s. 5.

${ }^{44}$ Polacy w New Britain, „Dziennik Chicagoski” nr 90, 17 kwietnia 1913, s. 5.

${ }^{45}$ Ks. L. BóJnOwski, Historja parafji polskich w diecezji hartfordskiej, s. 121-122. 
1897 r. ks. Władysław Kisielewicz ${ }^{46}$, który dojeżdżał do Polaków w Hartford i Litwinów w New Britain; od 16 lipca 1899 r. do 11 kwietnia 1907 r. ks. Józef Culkowski7; od 7 grudnia 1900 r. do 21 listopada 1904 r. ks. Franciszek Węgrzynowski ${ }^{48}$; od 5 do

${ }^{46}$ Urodził się 11 czerwca 1868 r. w Leżajsku. Świadectwo dojrzałości uzyskał w 1888 r. w Rzeszowie, następnie podjął studia w seminarium duchownym w Przemyślu, gdzie 20 lipca 1892 r. przyjął święcenia kapłańskie. Jeszcze tegoż roku wyjechał do Stanów Zjednoczonych. Od 1 września 1892 r. do 30 czerwca 1897 r. był profesorem w polskim seminarium duchownym w Detroit, a od 1 lipca do października tegoż roku duszpasterzował wśród Polaków i Litwinów w Hartford, Connecticut. Do Hamburga przybył 1 listopada 1897 r., gdzie podjął posługę duszpasterską wśród rodaków w kościele św. Michała - (mniejszym) do 1906 r. Następnie był proboszczem w Nisku (1906-1910), Stobierni (1910-1916) i Staromieściu k. Rzeszowa, gdzie zmarł 10 września 1943 r. Archiwum Archidiecezjalne w Przemyślu. Akta pers. ks. W. Kisielewicza; ks. A. NAdolny, Sto lat polskiego duszpasterstwa w Hamburgu, Pelplin-Hamburg 1992, s. 24; ks. B. Kumor, Kościelne dzieje Polonii w Connecticut, s. 255; Polacy w Ameryce, „Dziennik Chicagoski” nr 146, 25 czerwca 1895, s. 2; Polacy w Ameryce, „Dziennik Chicagoski” nr 240, 15 października 1895, s. 4; Seminarium w Detroit, „Dziennik Chicagoski” nr 99, 29 kwietnia 1897, s. 4; Z Domu Emigracyjnego Polskiego pod opieka Tow. Św. Józefa w New Yorku, „Dziennik Chicagoski” nr 184, 7 sierpnia 1899, s. 2; L. BieleCKi, Polacy w Hamburgu, „Dziennik Chicagoski” nr 253, 27 października 1899, s. 6; Wspomnienie z Hamburga, „Dziennik Chicagoski” nr 162, 12 lipca 1900, s. 1; Wspomnienie z Hamburga (Dokończenie), „Dziennik Chicagoski” nr 163, 13 lipca 1900, s. 2; Polacy na obczyźnie, „Dziennik Chicagoski” nr 6, 8 stycznia 1901, s. 4; Dom Św. Józefa do Braci Rodaków i Przyjaciót Domu Polskiego Emigracyjnego w Nowym Jorku, „Dziennik Chicagoski” nr 7, 9 stycznia 1903, s. 4.

${ }^{47}$ Urodził się 5 lutego 1875 r. w Rogoźnie, w Wielkim Księstwie Poznańskim. Do Ameryki przybył wraz z rodzicami w 1882 r., ukończył szkołę średnią św. Wojciecha, skąd udał się na dalsze studia filozoficzne do Kolegium św. Kanizjusza. Teologię ukończył w Seminarium Polskim w Detroit. Tamże, 2 lipca 1889 r. przyjął święcenia kapłańskie. Obowiązki wikariusza pełnił w New Britain, Conn., następnie w Bridgeport, od 29 stycznia 1900 r. w Norwich, a proboszczem został 13 marca 1902 r. w Meriden, Conn. Z powodu złego stanu zdrowia ustąpił z urzędu i został rezydentem w New Britain. Skąd w styczniu 1909 r. przybył do Buffalo i zatrzymał się u swej siostry pn. 447 Sweet ave. Zmarł 28 sierpnia 1909 r. w Buffalo, N.Y. i tam został pochowany. Śp. ks. Józef Culkowski, „Dziennik Chicagoski” nr 208, 4 września 1909, s. 5; ks. B. Kumor, Kościelne dzieje Polonii w Connecticut, s. $232,236,239,244,253$.

${ }^{48}$ Urodził się 3 września 1850 r. w Polsce. Święcenia kapłańskie przyjął 28 czerwca 1897 r. W lutym 1898 r. objął obowiązki wikariusza w parafii św. Stanisława Kostki w Shamokin. Następnie został proboszczem parafii NSJ w Cleveland. W lipcu 1900 r. opuścił parafię NSJ na Krakowie i udał się do stanu Pensylwania. Ostatecznie w lipcu 1901 r. wyjechał z New Britain i zatrzymał się w Baltimore - parafia NMP Różańcowej na kilka tygodni przed wyjazdem do Europy. Od 1902 r. do 1904 r. był proboszczem w Middletown i Portland. Polacy w Ameryce. Z Shamokin, Pa., „Dziennik Chicagoski” nr 48, 28 lutego 1898, s. 2; Polacy w Ameryce. Z Clevland, O., „Dziennik Chicagoski” nr 272, 20 listopada 1899, s. 4; Z Clevland, O., „Dziennik Chicagoski” nr 160, 10 lipca 1900, s. 2; Z Baltimore Md., „Dziennik Chicagoski” nr 156, 5 lipca 1901, s. 2; ks. B. Kumor, Kościelne dzieje Polonii w Connecticut, s. 236, 259. 
12 września 1901 r. ks. Michał Miklaszewski ${ }^{49}$; od 15 września do 15 października 1901 r. ks. Władysław Rakowski ${ }^{50}$; od 6 stycznia do 12 marca 1902 r. ks. Jan Ambot $^{51}$; od 11 lipca do 15 sierpnia 1902 r. ks. Edward Umiński ${ }^{52}$; od 4 do 11 września

${ }^{49}$ Urodził się 27 września 1850 r. Święcenia kapłańskie przyjął 13 czerwca 1877 r. w Przemyślu. Od 1895 r. był proboszczem parafii św. Michała w Junction, Wis., później parafii św. Wojciecha w Alban, Wis., do 21 stycznia roku 1900. „Po nieudanych próbach kolonizacyjnych w Stanach Idaho i Utah, ks. Michał Miklaszewski, rodem spod Sanoka w Galicyi przyszedł tu na daleki Wschód i objął tę parafię w Meriden; ale już 2 kwietnia r. 1902. wyjechał stąd do republiki Guatemali w Centralnej Ameryce"; W. KruszKa, Historya polska w Ameryce, t. 7, s. 21, 24; tamże, t. 11, s. 60; tamże, t. 13, s. 64; ks. B. Kumor, Kościelne dzieje Polonii w Connecticut, s. 236, 245, 256.

${ }^{50}$ Pochodził z Poznańskiego, w Stanach Zjednoczonych pełnił posługę duszpasterską w Duluth, Minn. Od roku 1902 pracował w parafii śś. Piotra i Pawła w St. Joseph, Mo., gdzie wybudował plebanię i w roku 1904 gotycką świątynię. W. KruszKa, Historya polska w Ameryce, t. 11, s. 60; ks. B. Kumor, Kościelne dzieje Polonii w Connecticut, s. 257.

${ }^{51}$ Urodził się 22 stycznia 1869 r. w Kownie na Litwie. Początkowe nauki pobierał w rodzinnym mieście. Po przybyciu do Ameryki, kontynuował dalsze studia w Kolegium św. Cyryla i Metodego w Detroit, Mich. Studia teologiczne odbył w Seminarium św. Jana w Brighton, Mass. Święcenia kapłańskie przyjął 19 grudnia 1901 r. z rąk bpa M. Tierneya w Hartford i został wikariuszem w polskim kościele w New Britain. Potem został przeniesiony do parafii pw. Panny Maryi w Greenwille. W roku 1904 został proboszczem w Norwich, Conn., a w 1912 r. objął parafię litewską Świętej Trójcy w Hartford. Zmarł 19 grudnia 1963 r. Z Hartford, Conn., „Dziennik Chicagoski” nr 221, 18 września 1912, s. 2; P. Kolenkiewicz, Z życia Polaków w Ameryce. Z Norwich, Conn., „Dziennik Chicagoski” nr 194, 21 sierpnia 1905, s. 2; ks. B. Kumor, Kościelne dzieje Polonii w Connecticut, s. 239, 244, 252.

${ }^{52}$ Urodził się 8 czerwca 1860 r. we wsi Mysłakówek. Po ukończeniu seminarium nauczycielskiego w Skępem pracował jako nauczyciel. W 1883 r. podjął studia w Seminarium Duchownym w Płocku. Święcenia kapłańskie przyjął 7 października 1888 r. z rąk bpa H. Kossowskiego. Posługę duszpasterską podjął jako wikariusz w Myszyńcu. Od 21 listopada tegoż roku, w tym samym charakterze pracował w Andrzejewie. W 1889 r. pracował w Ostrowii, skąd w 1892 r. został przeniesiony do Kadzidła. W 1899 r. ponownie pracował jako wikariusz w Myszyńcu. Za działalność narodowo-patriotyczną był poszukiwany przez władze rosyjskie, skąd zbiegł do Prus, a następnie do Ameryki Północnej, gdzie podjął posługę duszpasterską. W lipcu 1903 r. podjął posługę duszpasterską jako wikariusz przy irlandzkim kościele w New Bedford, Mass., a z początkiem listopada został mianowany przez ks. bpa Harkinsa z Providence proboszczem nowo założonej parafii pw. MB od Nieustającej Pomocy dla Polaków i podjął się budowy kościoła w New Bedford. Zmarł w 1937 r. w Nowym Jorku. Ks. M.M. GrZYBowski, Duchowieństwo diecezji płockiej. Wiek XIX, t. 3, Płock 2012, s. 261-262; P. KUBICKI, Bojownicy kapłani za sprawe Kościoła i Ojczyzny w latach 1861-1915. Materiały z urzędowych świadectw władz rosyjskich, archiwów konsystorskich, zakonnych i prywatnych, część 1, Dawne Król. Polskie, t. II, Diecezje lubelska z podlaska i płocka, Sandomierz 1933, s. 628-629; W. Kruszka, Historya polska w Ameryce, t. 13, s. 66; Polacy w Ameryce. Z New Bedford, Mass., 22 lutego 1904 r., „Dziennik Chicagoski” nr 54, 4 marca 1904, s. 3; Polacy w Ameryce. Z New Bedford, Mass., „Dziennik Chicagoski” nr 152, 28 czerwca 1904, s. 4; Z New Bedford, Mass., „Dziennik Chicagoski” nr 225, 27 września 1905, s. 2; Z New Bedford, Mass., „Dziennik Chicagoski” nr 293, 19 grudnia 1905, s. 2. 
1902 r. ks. Franciszek Czarniecki53 ${ }^{53}$ od 25 października do 23 listopada 1902 r. ks. Wincenty Buchowiecki; od 22 stycznia do 15 czerwca 1904 r. ks. Walenty Cichy $^{54}$; od 15 października 1904 r. do 17 kwietnia 1905 r. ks. Jan Mardyrosiewicz ${ }^{55}$; od 16 marca do 27 kwietnia 1905 r. ks. Karol Wotypka ${ }^{56}$; od 28 kwietnia do 26 października 1905 r. ks. Jan Raniszewski ${ }^{57}$; od 26 października 1905 r. do 23 sierpnia 1906 r. ks. Jan Ceppa ${ }^{58}$; od 1 lipca 1907 r. do 16 czerwca 1909 r. ks. Teodor Zimmerman $^{59}$; od 1 lipca do 30 września 1908 r. ks. Jan Mard ${ }^{60}$; od 1 września 1909 r.

${ }^{53}$ Ks. B. Kumor, Kościelne dzieje Polonii w Connecticut, s. 253.

${ }^{54}$ Mylna wiadomość, „Dziennik Chicagoski” nr 205, 2 września 1913, s. 4; Ks. Walenty Cichy naprawia zgorszenie, „Dziennik Chicagoski” nr 224, 24 września 1913, s. 4. Był duszpasterzem w Toledo; ks. B. Kumor, Kościelne dzieje Polonii w Connecticut, s. 245, 253.

${ }^{55}$ Urodził się w 1856 r. w Kutach na Bukowinie. Wychowywał się w zakładzie dla sierot im. Torosiewicza we Lwowie. Po ukończeniu gimnazjum wstąpił na Wydział Prawa UJK, i po roku przeniósł się na Wydział Teologii. Po przyjęciu w 1880 r. święceń kapłańskich, został wikariuszem i podjął obowiązki katechety przy szkole Benedyktynek. Pięć lat później został proboszczem w Horodence, a w 1890 r. kanonikiem kapituły ormiańskiej i kierownikiem banku zastawniczego „Pius mons”. Funkcje dyrektora banku spełniał od roku 1888, do chwili oddania się w ręce sądu. Zeznania ks. Mardyrosiewicza, „Dziennik Chicagoski” nr 210, 7 września 1901, s. 6; Kanonik Mardyrosiewicz, „Kurjer Lwowski" nr 229, 19 sierpnia 1901, s. 1-3; nr 231, 22 sierpnia 1901, s. 5; nr 234, 24 sierpnia 1901, s. 5. W epilogu: „Po ukończonej rozprawie i po ewentualnym odsiedzeniu kary [8 miesięcy więzienia] ma podobno kanonik Mordyrosiewicz zamiar przejść na łono kościoła rzymsko-katolickiego i wyjechać do Ameryki, gdzie i może ślad jego czynów po nim zaginie”; Ks. Mardyrosiewicz, „Dziennik Chicagoski” nr 167, 16 lipca 1904, s. 7. „Ks. Mardyrosiewicz, po odcierpieniu kary za malwersacye w banku ormiańskim, we Lwowie, poddał się pokucie kościelnej, którą odprawia w Krakowie. Po odbyciu pokuty ks. M. wyjeżdża do Ameryki”.

${ }^{56}$ Urodził się 16 grudnia 1865 r. w Czechach. Święcenia kapłańskie przyjął 25 sierpnia $1889 \mathrm{r}$. Od 1905 r. objął obowiązki proboszcza w parafii św. Józefa w Rockville. Zmarł 6 grudnia 1908 r. Ks. B. Kumor, Kościelne dzieje Polonii w Connecticut, s. 239, 259.

${ }^{57}$ Urodził się 11 listopada 1879 r. w USA. Święcenia kapłańskie przyjął 11 czerwca 1904 r. W 1917 r. był proboszczem w Middletown. Zmarł 15 czerwca 1945 r. Z życia Polaków w Ameryce. Z Norwich, Conn., „Dziennik Chicagoski” nr 194, 21 sierpnia 1905, s. 2; ks. B. Kumor, Kościelne dzieje Polonii w Connecticut, s. 236-237, 240-241, 257.

${ }^{58}$ Urodził się 24 listopada 1880 r. w Polsce. Studia teologiczne ukończył we Fryburgu. Święcenia kapłańskie przyjął 2 lutego 1905 r. w Louvain. Od 1906 r. był proboszczem w parafii św. Stanisława B.M. w Meriden. Tamże zmarł 3 maja 1948 r. Z Meriden, Conn., „Dziennik Chicagoski” nr 226, 26 września 1908, s. 5; ks. B. Kumor, Kościelne dzieje Polonii w Connecticut, s. 236, 244, 249, 253

${ }^{59}$ Od 1914 r. był proboszczem w parafii św. Stanisława Kostki w Waterbury, gdzie zmarł 20 lipca 1920 r. Z Meriden, Conn., „Dziennik Chicagoski” nr 226, 26 września 1908, s. 5; ks. B. Kumor, Kościelne dzieje Polonii w Connecticut, s. 241, 243, 259.

${ }^{60}$ Z Meriden, Conn., „Dziennik Chicagoski” nr 226, 26 września 1908, s. 5; Poświęcenie szkoty polskiej N. Serca Jezusowego, w New Britain, Conn., „Dziennik Chicagoski” nr 212, 13 września 1910, s. 5. Był wówczas proboszczem w Easthampton, Mass. 
do 18 marca 1910 r. ks. Tomasz Krakowiak ${ }^{61}$; od 1 marca 1909 r. do 1 lipca 1910 r. ks. Anzelm Młynarczyk ${ }^{62}$; od 9 lipca do 6 września 1910 r. ks. Ludwik Wojtyśs ${ }^{63}$; od 8 września 1910 r. do 30 grudnia 1911 r. ks. Szymon Nawrocki ${ }^{64}$; od 10 listopada 1911 r. do 8 marca 1916 r. ks. Franciszek Władasz ${ }^{65}$, przybyły przed rokiem 1912 z ojczystego kraju. On też organizował prymicje kapłańskie ks. Zygmuntowi Woronieckiemu ${ }^{66}$, pochodzącemu z tej parafii ${ }^{66}$.

${ }^{61}$ Urodził się 7 grudnia 1883 r. w miejscowości Słotwiny. Po ukończeniu gimnazjum w Płocku, w 1901 r. wstąpił do miejscowego seminarium duchownego. Święcenia kapłańskie przyjął 30 czerwca 1907 r. z rąk bpa A. Wnukowskiego. Został wikariuszem w Chorzelach. 23 lipca 1909 r. wyjechał do Ameryki Północnej, gdzie w New Britain od 1 września 1909 r. do 18 marca 1910 r. jako wikariusz pełnił obowiązki duszpasterskie. Do diecezji powrócił w 1913 r. 7 lutego 1914 r. został wikariuszem w Broku. W marcu 1922 r. został proboszczem w Radzanowie koło Płocka, 1 maja 1925 r. - w Ciachcinie, a 22 lutego 1932 r. - w Chociszewie. Zmarł 22 listopada 1937 r. Pochowany został na cmentarzu parafialnym w Chociszewie. Ks. M.M. GRzYBowski, Duchowieństwo diecezji płockiej. Wiek XIX, t. I, cz. 2, Płock 2008, s. 180-181; Śp. ks. Tomasz Krakowiak, „Miesięcznik Pasterski Płocki” 1937, nr 12, s. 593; New Britain. Conn., „Dziennik Chicagoski” nr 215, 14 września 1909, s. 6. „Dnia 2 września przybył tu młody kapłan Wiel. ks. Tomasz Krakowiak, z Płockiej dyecezyi, z Kongresówki i będzie pracował w parafii polskiej Najsł. Serca Jezusowego".

${ }^{62}$ W 1896 r. był rektorem kościoła w Detour i założycielem polskiej kolonii w Gatesville. Był wikariuszem w La Salle, Ill. i został proboszczem parafii św. Jana w Lathrobe, Pensylwania. Gatesville, Mich., „Dziennik Chicagoski” nr 302, 28 grudnia 1904, s. 4; Z Kazimierzowa, „Dziennik Chicagoski” nr 242, 15 października 1902, s. 4; Rosya, Japonia, Polacy i uczciwi Amerykanie, „Dziennik Chicagoski” nr 30, 6 lutego 1905, s. 2. Z New Kenstington, Pa., apelował o pomoc jeńcom polskim w Japonii.

63 „Parafię w Mc. Due, w marcu 1906 r. objął ks. Ludwik Wojtyś”. Z Filadelfii, Pa., „Dziennik Chicagoski” nr 63, 20 marca 1906, s. 2; ks. B. Kumor, Kościelne dzieje Polonii w Connecticut, s. 259.

${ }^{64}$ W latach 1910-1912 był wikariuszem w parafii pw. św. Wojciecha w Filadelfii, następnie profesorem w Kolegium św. Jana Kantego. Historia polskich rzymsko-katolickich parafij archidiecezji filadelfijskiej, s. 88, 158, 211; ks. B. Kumor, Kościelne dzieje Polonii w Connecticut, s. 256.

${ }^{65}$ Urodził się 27 września 1884 r. w Polsce. Studia teologiczne ukończył we Fryburgu. Święcenia kapłańskie przyjął 2 lipca 1911 r. Od 10 listopada 1911 r. do 8 marca 1916 r. był wikariuszem w New Britain. W marcu 1916 r. został proboszczem parafii św. Józefa w Suffield. W 1918 r. został proboszczem w parafii św. Józefa w Rockville, a w 1922 r. - parafii Imienia Jezus w Stamford, gdzie zmarł 26 czerwca 1959 r. Ks. B. Kumor, Kościelne dzieje Polonii w Connecticut, s. 239-241, 244, 249.

${ }^{66}$ Urodził się 20 czerwca 1884 r. w Ciechocinie, k. Lipna, w gub. płockiej. Do Ameryki przybył mając lat 16 i zamieszkiwał przez pewien czas w New Britain, Conn., z bratem swoim, który był organistą przy kościele polskim Najsł. Serca Jezusowego, a później objął to samo stanowisko w parafii św. Wojciecha B. i M. w Buffalo, N.Y. Z New Britain udał się na studia do Seminarium Polskiego w Orchard Lake, Mich. (Detroit) i tam ukończył gimnazjum oraz kurs filozoficzny i teologiczny. 24 czerwca 1913 r. w katedrze św. Józefa w Hartford, Conn., przyjął święcenia kapłańskie z rąk bpa J. Nilana, i został wikariuszem w New Britain. Od 1915 r. został proboszczem w parafii Niepokalanego Poczęcia NMP w Southington. Od 1927 r. był proboszczem w parafii św. Józefa w Rockville, gdzie zmarł 10 października 1949 r. Wiadomości drobne z Nowej Anglii. W Hartford, Conn., „Dziennik 
Kolejnymi duszpasterzami, którzy podjęli posługę duszpasterską w New Britain, byli: od 28 czerwca do 31 sierpnia 1912 r. ks. Stanisław Federkiewicz ${ }^{68}$; od 8 lipca do 2 grudnia 1912 r. ks. Piotr Basiński' ${ }^{69}$; od 25 czerwca 1913 r. do 12 sierpnia 1914 r. ks. Zygmunt Woroniecki ${ }^{70}$; od 1 października do 4 grudnia 1913 r. ks. Wacław Kolman ${ }^{71}$; od 13 sierpnia 1914 r. do 30 listopada 1918 r. ks. Stanisław Grochol $^{72}$; od 8 marca 1916 r. do 23 kwietnia 1919 r. ks. Stanisław Błażejowski ${ }^{73}$; od 16 czerwca 1916 r. do 5 listopada 1917 r. ks. Teofil Czarkowski ${ }^{74}$; w 1917 r. ks. Antoni Trałka ${ }^{75}$; od 24 lutego 1917 r. do 4 czerwca 1918 r. ks. Franciszek Młynarski ${ }^{76}$; od 7 stycznia 1918 r. do 31 stycznia 1921 r. ks. Bolesław Dutkiewicz ${ }^{77}$; od 23 kwietnia 1919 r. do 15 stycznia 1925 r. ks. Aleksander Tański ${ }^{78}$ i od 2 stycznia 1921 r. do 1 maja 1922 r. ks. Jan Taranowicz ${ }^{79}$. Poza tym w prowadzenie parafii

Chicagoski” nr 161, 11 lipca 1913, s. 5; Z New Britain Conn., „Dziennik Chicagoski” nr 171, 23 lipca 1913, s. 8; ks. B. Kumor, Kościelne dzieje Polonii w Connecticut, s. 239-240, 246, 259.

${ }^{67}$ Z New Britain, Conn., „Dziennik Chicagoski” nr 221, 18 września 1912, s. 4.

${ }^{68}$ Urodził się 25 kwietnia 1866 r. w Polsce. Święcenia kapłańskie przyjął 21 czerwca 1912 r. Od 1915 r. był proboszczem w parafii św. Wojciecha w Enfield - do 1936 r. Zmarł 27 grudnia 1938 r. Ks. B. Kumor, Kościelne dzieje Polonii w Connecticut, s. 234, 254.

${ }^{69}$ Przez trzy lata był proboszczem w Albion, N. Y. W 1900 r. został przeniesiony do parafii św. Jana Kantego w Buffalo. J. Cichocki, Z Albion, N. Y., „Dziennik Chicagoski” nr 19, 23 stycznia 1900, s. 2; Z New Britain, Conn., „Dziennik Chicagoski” nr 221, 18 września 1912, s. 4. „... prefekt szkoły parafialnej”; ks. B. Kumor, Kościelne dzieje Polonii w Connecticut, s. 252.

70 Zob. przyp. 65.

${ }^{71}$ Z Orchard Lake, Mich., „Dziennik Chicagoski” nr 138, 13 czerwca 1913, s. 6.

${ }^{72}$ New Britain, Conn., 17-go maja 1918, „Dziennik Chicagoski” nr 120, 22 maja 1918, s. 6; ks. B. Kumor, Kościelne dzieje Polonii w Connecticut, s. 253.

${ }^{73}$ Urodził się 29 sierpnia 1891 r. w Polsce. 28 lipca 1915 r. przyjął z rąk bpa J.J. Nilana w katedrze św. Józefa w Hartford, Conn., święcenia kapłańskie. Od 1920 r. był proboszczem parafii św. Stanisława Kostki w Waterbury - do 1939 r. Zmarł 5 marca 1946 r. Middletown, Conn. Prymicye ks. Stanisława Błażejowskiego, „Dziennik Chicagoski” nr 184, 7 sierpnia 1915, s. 6; ks. B. Kumor, Kościelne dzieje Polonii w Connecticut, s. 243, 246, 253.

${ }^{74}$ Urodził się w 1883 r. w Polsce. Święcenia kapłańskie przyjął w 1906 r. Od 1917 r. był proboszczem w parafii MB Nieustającej Pomocy w New London - do 1920. Ks. B. Kumor, Kościelne dzieje Polonii w Connecticut, s. 237.

${ }^{75}$ New Britain, Conn., „Dziennik Chicagoski” nr 102, 2 maja 1914, s. 14.

${ }^{76}$ Co mówi zacny kapłan polski o pożyczce, „Dziennik Chicagoski” nr 124, 25 maja 1920, s. 6.

${ }^{77}$ Ks. B. Kumor, Kościelne dzieje Polonii w Connecticut, s. 253.

${ }^{78}$ Urodził się 11 września 1886 r. w Polsce. Święcenia kapłańskie przyjął 20 października 1918 r. Od 1927 r. był proboszczem w parafii Niepokalanego Poczęcia NMP w Southington - do 1967. Zmarł 28 maja 1980 r. Z Sejmu Zjednoczenia Kapłanów Polskich w Ameryce, „Dziennik Chicagoski” nr 47, 25 lutego 1921, s. 5; ks. B. Kumor, Kościelne dzieje Polonii w Connecticut, s. 240.

79 Z naszej prasy: „,Przewodnik Katolicki”, „Dziennik Chicagoski” nr 180, 3 sierpnia 1921, s. 4; ks. B. Kumor, Kościelne dzieje Polonii w Connecticut, s. 258. 
i dzieł realizowanych przy niej włączali się członkowie towarzystw kościelnych, których „w parafii polskiej było wiele" $"$.

W polityce miejscowej Polacy nie odgrywali roli takiej, jaką mogliby przy wspólnej, intensywnej pracy. Dzieląc się na republikanów i demokratów, ograniczali swoje możliwości i znaczenie, stając się narzędziem amerykańskich polityków. Kandydaci polscy na urzędy miejskie, skutkiem podziału głosów polskich na dwie partie, zwycięstwo oddawali kandydatom innych narodowości ${ }^{81}$. Stąd ks. L. Bójnowski, od chwili podjęcia obowiązków duszpasterskich w New Britain, mierząc się z tym wyzwaniem wielokrotnie, wprost apelował do rodaków zamieszkałych w mieście i w stanie Connecticut o solidarność, o konieczność organizowania się w różnych strukturach. Najpierw, w czasie misji świętych w New Britain (3-18 czerwca 1899 r.) prowadzonych przez polskich jezuitów z Galicji, zachęcał do organizowania się Polaków. W tym celu, kilka miesięcy później, 12 października wydał nawet odezwę do Polaków w Connecticut względem organizowania się, a 26 października zwołał do New Britain zebranie Polaków na 30 listopada, na którym postanowiono założyć organizację Unia Polska. W celu koordynowania wysiłków imigrantów polskich zmierzających do tworzenia własnych parafii etnicznych, organizację taką powołano 20 maja 1900 r. pod opieką Niepokalanego Poczęcia NMP ${ }^{82}$. Ksiądz Bójnowski usiłując zwrócić uwagę rodaków na wspomniany problem napisał:

Krótki więc czas oddziela nas od tej chwili, w której mamy zadecydować, czy my, Polacy Katolicy zamieszkali w miastach i miasteczkach Nowej Anglii (New England), mamy tu istnieć nadal jako Polacy, czy też powoli zginąć w morzu amerykanizmu. A chociaż i czas krótki i sprawa ważna, w wielu osadach w stanie Connecticut Polacy bardzo mało albo jeszcze nic nie zrobili, aby wysłać od siebie delegatów na sejm do Bridgeport, Conn. Przykro to nadzwyczaj, że tak mało dbamy o siebie. Postanowiłam przeto za łaskawem pośrednictwem czasopism polskich zachęcić was, Bracia, abyście sprawy nie zasypiali, ale chętnie wzięli się do dzieła. [...] chodzi o zachowanie naszej wiary św. rzymsko katolickiej i narodowości polskiej i o przekazanie tych klejnotów naszym potomkom ${ }^{83}$.

${ }^{80}$ W 1912 r. Towarzystwo Najsłodszego Imienia Jezus obchodziło 15 lecie istnienia. Liczyło blisko 300 członków; Z New Britain, Conn., „Dziennik Chicagoski” nr 221, 18 września 1912, s. 4; ks. L. BójNowsKi, Historja parafji polskich $w$ diecezji hartfordskiej, s. 94-98.

${ }^{81} \mathrm{Z}$ apelem w obronie obywateli pochodzenia polskiego, o ich należyte traktowanie wystąpił radny miejski Pajewski w artykule zamieszczonym na łamach „New Britain Herald”. „Pomimo że Polacy stanowią większość mieszkańców miasteczka New Britain, podczas wyborów zawsze są oni uważani, za najsłabszy element wyborczy. Politycy zabiegają głównie o względy Włochów i osób innej narodowości. Polaków zawsze ignorują”. Z New Britain, Conn., „Dziennik Chicagoski” nr 240, 13 października 1922, s. 3.

${ }^{82}$ Ks. B. Kumor, Kościelne dzieje Polonii w Connecticut, s. 220-223.

${ }^{83}$ Do Polaków Katolików w Stanie Connecticut, ,Dziennik Chicagoski” nr 119, 22 maja 1901, s. 5. 
W praktyce, każde wydarzenie spotkało się z odzewem tak proboszcza, jak i parafian. W listopadzie 1917 r. w Stanach Zjednoczonych gotowość wstąpienia do Armii Polskiej we Francji zgłosiło 35395 osób. W czasie I wojny światowej Polonia w New Britain złożyła na cele polskie 182 911,84 dol..$^{84}$ Proboszcz osobiście angażował się w rekrutację poborowych ${ }^{85}$. Z New Britain wysłano: „29 listopada 1917 r. 82 ochotników, 1 stycznia 1918 r. 10 ochotników, 10 stycznia 1918 r. 6 ochotników. Razem 98 ochotników" ${ }^{86}$. W maju dołączyło kolejnych 14 ochotników ${ }^{87}$. Proboszcz zainicjował też zbiórkę na fundusz milionowy ${ }^{88}$, na który parafia złożyła 35 tys. dolarów ${ }^{89}$. Czasem na bieżąco wierni stawiali czoła wyzwaniom, które pociągały za sobą wydatki z kasy parafialnej - podczas zdarzeń losowych, podczas burzy, gdy np. piorun uderzył w wieżę polskiego kościoła Najsłodszego Serca Jezusa przy Broad str. i spowodował pożar ${ }^{90}$.

Swoje zaangażowanie w trosce o Polaków i Polskę ks. Bójnowski przedstawił w liście skierowanym do generała Józefa Hallera goszczącego wówczas w Stanach Zjednoczonych:

Jako założyciel i proboszcz przez 28 lat w parafji polskiej Najśw Serca Jezusowego w New Britain, Conn. i jako były oficer rekrutacyjny polskich wojsk w Ameryce, oraz członek Obrony Krajowej Stanów Zjednoczonych w stanie Connecticut, (To znaczy: że należałem do Komisji wojennej amerykańskiej w stanie Connecticut w czasie wojny wszechświatowej, i bywałem na naradzie wojennej przynajmniej raz na tydzień u gubernatora), upraszam w imieniu swoim, ażeby Sz. Pan Generał z łaski swojej raczył

${ }^{84}$ Ks. B. Kumor, Z problemów ludnościowych polskiej parafii Najśw. Serca Jezusowego w New Britan, Conn., s. 262.

${ }^{85}$ Z obozu Kościuszki, „Dziennik Chicagoski” nr 297, 19 grudnia 1917, s. 10.

${ }^{86}$ Biuletyn Armii Polskiej. Centrum No. 41 w New Britain, Conn., „Dziennik Chicagoski” nr 64, 16 marca 1918 , s. 6.

${ }^{87}$ New Britain, Conn., 17-go maja 1918, „Dziennik Chicagoski” nr 120, 22 maja 1918, s. 6.

${ }^{88}$ New Britain, Conn., „Dziennik Chicagoski” nr 212, 10 września 1918, s. 2. „Sejm Wychodztwa Polskiego pomyślnie przeprowadził największe swoje zadanie, tworząc stały Wydział Wykonawczy, składający się z 15-tu członków, w celu kierowania czynnościami wojennemi cztero-milionowego narodu polskiego w Stanach Zjednoczonych. [...] Zadaniem organizacyi jest wspomagać w wojnie Aliantów i zabezpieczenie niepodzielności i niepodległości wszystkich ziem polskich. Sejm Wychodztwa Polskiego uchwalił dalej: Pierwsze: zebrać fundusz dziesięcio-milionowy na cele wspomożenia Sprawy Polskiej i Armii Polskiej we Francyi. Drugie: zorganizowanie wielkiej armii z żołnierzy polskich, porozrzucanych po całej Rosyi. Trzecie: popieranie Polskiego «Białego Krzyża», który pracuje wyłącznie tylko dla Armii Polskiej. Czwarte: zebrać od każdego pracującego Polaka dobrowolnej składki rocznej $\$ 6.00$, lub więcej, jeżeli zarobek tegoż przewyższa więcej jak $\$ 1,800$ rocznie”.

89 O zdobycie milionów (Z Wydziału Narodowego), ,Dziennik Chicagoski” nr 300, 23 grudnia 1918, s. 10.

${ }^{90}$ Z New Britain, Conn., „Dziennik Chicagoski” nr 141, 17 czerwca 1918, s. 6. Zdarzenie miało miejsce 23 maja 1918 r., zaistniałą szkodę obliczono na $\$ 7,000$. 
choć na chwilkę wstąpić w progi moje i zobaczyć co Polacy zdziałali w New Britain dla siebie i dla Ojczyzny i Ameryki i podziękować Polakom i Amerykanom za pracę. [...] My pierwsi w całej Ameryce przed wojną wszechświatową zawiązaliśmy w New Britain Komitet Obywatelski. Dziś jeszcze posiadamy protokóły, a jeden bardzo ważny z dnia 2-go Maja 1915 r. gdzie postanowiliśmy trzymać z aljantami i posyłać pieniądze do sz. p. H. Sienkiewicza w Szwajcarji. [...] Przed rozpoczęciem wojny zebraliśmy dolarów 1,000.00 na Oswobodzenie Ojczyzny, które w czasie wojny zostały wręczone sz. p. Paderewskiemu dnia 23-go stycznia 1917 r. w Gotham Hotel New York, [...] Razem, wszystkiego przed i we wojnie $870,172.80$

Do armii amerykańskiej pierwszy oddział wyjechał z New Britain dnia 5-go września 1917 r. a ostatni w październiku 1918 r. - razem poszło Polaków do armji amerykańskiej 675

Do armji polskiej pierwszy oddział wyjechał z New Britain 82 członków 29-go listopada 1917 r., a ostatni oddział 3-go lutego 1919 r.

Do armji polskiej wstąpiło ochotników - razem 290

do armji Polskiej i Amerykańskiej razem Polaków wstąpiło 965.

Z New Britain zabito w polskiej i amerykańskiej armji Polaków i nie Polaków 123

Wszystkiego z New Britain poszło do wojska 3,800 co stanowi co czwarty żołnierz to Polak - a mężczyzn polskich, było wtedy w parafji 3,500, co stanowi, że co trzeci to poszedł do wojska. Że więcej nie wstąpiło do armji polskiej, wina śmietanki polskiej w New Britain, która trzymała z Niemcami, a potem brano Polaków do armji Amerykańskiej.

Na ostatnim Sejmie Wychodźtwa w Pittsburghu, sz.p. Smulski, prezes Wydziału Narodowego, zdając sprawozdanie na Sejmie publicznie przyznał nam pierwszeństwo w całej Ameryce na polu pracy i ofiar. [...] 6. My jako parafja, najwięcej daliśmy ofiar, żadna parafja tyle nie dała ${ }^{91}$.

Rola polskiej parafii etnicznej w New Britain w Stanach Zjednoczonych była i jest znacząca. Więź emigrantów polskich z Kościołem poza ojczystym krajem kształtowała poczucie tożsamości religijnej i narodowej. W parafii polskiej odnajdywano więź ze starym krajem, w kościele szukano okazji do właściwego przeżywania doświadczeń religijnych. Jakkolwiek były one znane w całym Kościele, to jednak wśród ludu polskiego miały specjalny polski koloryt.

Parafia polska w New Britain odegrała istotną rolę kulturalną. Prowadziła szkołę, przedszkole, sierociniec, chór kościelny, bibliotekę, wydawała własne pismo „Przewodnik Katolicki”. Wokół parafii swoją działalność prowadziły różne towarzystwa religijne, kulturalne i narodowe mające na celu pogłębianie i podtrzyma-

${ }^{91}$ Cyt. za: ks. L. Bójnowski, Historja parafji polskich w diecezji, s. 168-175; por. ks. J. SzYMaŃSKI, Parafie i duchowieństwo polskie w USA w walce o niepodległość Polski, „Archiwa, Biblioteki i Muzea Kościelne” 110(2018), s. 416-434. 
nie polskiej świadomości narodowej wśród emigrantów, więzi ze starym krajem, pogłębianie życia religijnego. Obok pomocy duchowej, uroczystych nabożeństw parafia polska dostarczyła do „błękitnej armii” wielu rekrutów, a także tysiące dolarów pomocy materialnej staremu krajowi. W strukturach tej parafii znaczącą rolę odegrali jej duszpasterze, którzy podjęli w niej posługę duszpasterską, oraz lokalni działacze, których zaangażowanie jest nie do przecenienia.

Ogromną rolę odegrała parafia polska przede wszystkim w sprawach odrodzenia poczucia narodowego i odrodzenia niepodległego Państwa Polskiego.

\section{BIBLIOGRAFIA}

Archiwum Archidiecezjalne w Przemyślu. Akta personalne ks. Władysława Kisielewicza. Bielecki L., Polacy w Hamburgu, „Dziennik Chicagoski” nr 253, 27 października 1899, s. 6.

Biuletyn Armii Polskiej. Centrum No. 41 w New Britain, Conn., „Dziennik Chicagoski” nr 64, 16 marca 1918, s. 6.

BóJNOwsKi L., ks., Historja parafji polskich w diecezji hartfordskiej w Stanie Connecticut w Stanach Zjednoczonych, New Britain, Conn., 1939.

Bósnowski L., ks., Poświęcenie Ochronki Polskiej w New Britain, Conn., „Dziennik Chicagoski" nr 119, 26 maja 1906, s. 3.

Bósnowski L., ks., Sprawozdanie z Ochronki Polskiej w New Britain Conn., „Dziennik Chicagoski" nr 51, 6 marca 1906, s. 2.

Bósnowski L., ks., Z New Britain Conn., „Dziennik Chicagoski” nr 33, 9 lutego 1897, s. 2.

Ciсноскі J., Z Albion, N.Y., „Dziennik Chicagoski” nr 19, 23 stycznia 1900, s. 2.

Co mówi zacny kapłan polski o pożyczce, „Dziennik Chicagoski” nr 124, 25 maja 1920, s. 6.

Dom Św. Józefa do Braci Rodaków i Przyjaciół Domu Polskiego Emigracyjnego w Nowym Jorku, „Dziennik Chicagoski” nr 7, 9 stycznia 1903, s. 4.

Do Polaków Katolików w Stanie Connecticut, „Dziennik Chicagoski” nr 119, 22 maja 1901, s. 5.

Fair w New Britain Conn., „Dziennik Chicagoski” nr 283, 10 grudnia 1897, s. 2.

Gatesville, Mich., „Dziennik Chicagoski” nr 302, 28 grudnia 1904, s. 4.

GrzYbowski M.M., ks., Duchowieństwo diecezji płockiej. Wiek XIX, t. I, cz. 2, Płock: Biblos 2008.

Grzybowski M.M., ks., Duchowieństwo diecezji płockiej. Wiek XIX, t. III, Płock: Biblos 2012.

Historia polskich rzymsko-katolickich parafij archidiecezji filadelfijskiej w Stanach Zjednoczonych Północnej Ameryki, Philadelphiae 1938.

Kanonik Mardyrosiewicz, „Kurjer Lwowski”, nr 229, 19 sierpnia 1901, s. 1-3; nr 231, 22 sierpnia 1901, s. 5; nr 234, 24 sierpnia 1901, s. 5. 
Kolenkiewicz P., Z życia Polaków w Ameryce. Z Norwich, Conn., „Dziennik Chicagoski” nr 194, 21 sierpnia 1905, s. 2.

Ks. Mardyrosiewicz, „Dziennik Chicagoski” nr 167, 16 lipca 1904, s. 7.

KruszKa W., Historya polska w Ameryce. Początek, wzrost i rozwój dziejowy osad polskich w Północnej Ameryce (w Stanach Zjednoczonych i Kanadzie), t. 7, 11, 13, Milwaukee, Wis., 1905-1908.

Która gazeta jest dobrą w Ameryce? „Dziennik Chicagoski” nr 39, 16 lutego 1909, s. 3.

Ks. Walenty Cichy naprawia zgorszenie, „Dziennik Chicagoski” nr 224, 24 września 1913, s. 4.

KuBICKi P., Bojownicy kapłani za sprawę Kościoła i Ojczyzny w latach 1861-1915. Materiały z urzędowych świadectw władz rosyjskich, archiwów konsystorskich, zakonnych i prywatnych, część 1, Dawne Król. Polskie, t. II, Diecezje lubelska z podlaską i płocka, Sandomierz 1933.

Kumor B., ks., Kościelne dzieje Polonii w Connecticut 1870-1986, „Nasza Przeszłość” 73(1990).

Kumor B., ks., Z problemów ludnościowych polskiej parafii Najśw. Serca Jezusowego w New Britan, Conn. (1895-1920), „Studia Polonijne” 5(1982).

Middletown, Conn. Prymicye ks. Stanisława Błażejowskiego, „Dziennik Chicagoski” nr 184, 7 sierpnia 1915, s. 6.

Mylna wiadomość, „Dziennik Chicagoski” nr 205, 2 września 1913, s. 4.

NAdolny A., ks., Sto lat polskiego duszpasterstwa w Hamburgu, Pelplin-Hamburg 1992.

New Britain, Conn., „Dziennik Chicagoski” nr 102, 2 maja 1914, s. 14.

New Britain. Conn., „Dziennik Chicagoski” nr 215, 14 września 1909, s. 6.

New Britain, Conn., 17-go maja 1918, „Dziennik Chicagoski” nr 120, 22 maja 1918, s. 6.

NIR R., Misicki Tomasz, w: Encyklopedia polskiej emigracji i Polonii, red. K. Dopierała, t. III, Toruń: Oficyna Wydawnicza Kucharski 2004, s. 323-324.

NIR R., Szkice z dziejów Polonii, Orchard Lake, Michigan: Wyd. Centralnego Archiwum Polonii Amerykańskiej 1990.

Notatki, „Dziennik Chicagoski” nr 42, 19 lutego 1908, s. 4.

(Od naszego specyalnego podróżującego korespondenta.) Korespondencye ze Wschodu, New Britain, Conn., „Dziennik Chicagoski” nr 90, 17 kwietnia 1913, s. 5.

O „niezależnym” Kamińskim, „Dziennik Chicagoski” nr 245, 21 października 1895, s. 2.

O zdobycie milionów (Z Wydziału Narodowego), „Dziennik Chicagoski” nr 300, 23 grudnia 1918, s. 10.

Polacy na obczyźnie, „Dziennik Chicagoski” nr 6, 8 stycznia 1901, s. 4.

Polacy w Ameryce, „Dziennik Chicagoski” nr 103, 3 maja 1893, s. 2.

Polacy w Ameryce, „Dziennik Chicagoski” nr 146, 25 czerwca 1895, s. 2.

Polacy w Ameryce, „Dziennik Chicagoski” nr 240, 15 października 1895, s. 4.

Polacy w Ameryce. W New Britain, Conn., „Dziennik Chicagoski” nr 229, 3 października 1894, s. 4.

Polacy w Ameryce. Z Clevland, O., „Dziennik Chicagoski” nr 272, 20 listopada 1899, s. 4.

Polacy w Ameryce. Z Hartford, Conn., „Dziennik Chicagoski” nr 236, 6 października 1902, s. 4. 
Polacy w Ameryce. Z New Bedford, Mass., „Dziennik Chicagoski” nr 152, 28 czerwca 1904, s. 4.

Polacy w Ameryce. Z New Bedford, Mass., 22 lutego 1904 r., „Dziennik Chicagoski” nr 54, 4 marca 1904, s. 3.

Polacy w New Britain, „Dziennik Chicagoski” nr 90, 17 kwietnia 1913, s. 5.

Poświęcenie szkoły polskiej N. Serca Jezusowego w New Britain, Conn., „Dziennik Chicagoski” nr 212, 13 września 1910, s. 5.

Potrzeba nauczycielek do szkoły polskiej, „Dziennik Chicagoski” nr 175, 29 lipca 1910, s. 7.

Prośba do Szanownego Społeczeństwa, „Dziennik Chicagoski” nr 82, 7 kwietnia 1922, s. 5.

Prośba do Szanownego Społeczeństwa, „Dziennik Chicagoski” nr 298, 21 listopada 1922, s. 7.

Polacy w Ameryce. Z Shamokin, Pa., „Dziennik Chicagoski” nr 48, 28 lutego 1898, s. 2.

Poświęcenie szkoły polskiej N. Serca Jezusowego, w New Britain, Conn., „Dziennik Chicagoski” nr 212, 13 września 1910, s. 5.

Rosya, Japonia, Polacy i uczciwi Amerykanie, „Dziennik Chicagoski” nr 30, 6 lutego 1905, s. 2.

Seminarium w Detroit, „Dziennik Chicagoski” nr 99, 29 kwietnia 1897, s. 4.

Szkoła polska w New Britain Conn., „Dziennik Chicagoski” nr 114, 15 maja 1909, s. 4.

SZYMAŃSKi J., ks., Parafie i duchowieństwo polskie w USA w walce o niepodległość Polski, „Archiwa, Biblioteki i Muzea Kościelne” 110(2018).

SzYMaŃski J., ks., Parafia w Meriden i jej duszpasterze na łamach „Dziennika Chicagoskiego” w latach 1893-1920, „Archiwa, Biblioteki i Muzea Kościelne” 114 (2020) [w druku].

Śp. ks. Józef Culkowski, „Dziennik Chicagoski” nr 208, 4 września 1909, s. 5.

Śp. ks. Tomasz Krakowiak, „Miesięcznik Pasterski Płocki” 1937, nr 12, s. 593.

Wiadomości drobne z Nowej Anglii. W Hartford, Conn., „Dziennik Chicagoski” nr 161, 11 lipca 1913, s. 5.

W New Britain, Conn., „Dziennik Chicagoski” nr 67, 21 marca 1911, s. 8.

W New Britain, Conn., „Dziennik Chicagoski” nr 271, 22 listopada 1911, s. 5.

W parafii polskiej św. Stanisława w Winonie, Minn., „Dziennik Chicagoski” nr 59, 10 marca 1893 , s. 1.

Wspomnienie z Hamburga, „Dziennik Chicagoski” nr 162, 12 lipca 1900, s. 1.

Wspomnienie z Hamburga (Dokończenie), „Dziennik Chicagoski” nr 163, 13 lipca 1900, s. 2.

Z Baltimore Md., „Dziennik Chicagoski” nr 156, 5 lipca 1901, s. 2.

Z Clevland, O., „Dziennik Chicagoski” nr 160, 10 lipca 1900, s. 2.

Z Domu Emigracyjnego Polskiego pod opieką Tow. Św. Józefa w New Yorku, „Dziennik Chicagoski" nr 184, 7 sierpnia 1899, s. 2.

Zeznania ks. Mardyrosiewicza, „Dziennik Chicagoski” nr 210, 7 września 1901, s. 6.

Z Filadelfii, Pa., „Dziennik Chicagoski” nr 63, 20 marca 1906, s. 2.

Z Hartford, Conn., „Dziennik Chicagoski” nr 221, 18 września 1912, s. 2.

Z Kazimierzowa, „Dziennik Chicagoski” nr 242, 15 października 1902, s. 4.

Z Meriden, Conn., „Dziennik Chicagoski” nr 226, 26 września 1908, s. 5.

Z naszej prasy: „Przewodnik Katolicki”, „Dziennik Chicagoski” nr 180, 3 sierpnia 1921, s. 4. 
Z New Bedford, Mass., „Dziennik Chicagoski” nr 225, 27 września 1905, s. 2.

Z New Bedford, Mass., „Dziennik Chicagoski” nr 293, 19 grudnia 1905, s. 2.

Z New Britain, Conn., „Dziennik Chicagoski” nr 141, 17 czerwca 1918, s. 6.

Z New Britain, Conn., „Dziennik Chicagoski” nr 171, 23 lipca 1913, s. 8.

Z New Britain, Conn., „Dziennik Chicagoski” nr 200, 27 sierpnia 1902, s. 4.

Z New Britain, Conn., „Dziennik Chicagoski” nr 212, 10 września 1918, s. 2.

Z New Britain, Conn., „Dziennik Chicagoski” nr 221, 18 września 1912, s. 4.

Z New Britain, Conn., „Dziennik Chicagoski” nr 240, 8 października 1913, s. 3.

Z New Britain, Conn., „Dziennik Chicagoski” nr 240, 13 października 1922, s. 3.

Z New Britain, Conn., „Dziennik Chicagoski” nr 272, 20 października 1899, s. 4.

Z New Britain, Conn., „Dziennik Chicagoski” nr 32, 7 lutego 1907, s. 5.

Z New Britain, Conn., „Dziennik Chicagoski” nr 34, 9 lutego 1912, s. 6.

Z obozu Kościuszki, „Dziennik Chicagoski” nr 297, 19 grudnia 1917, s. 10.

Z Orchard Lake, Mich., „Dziennik Chicagoski” nr 138, 13 czerwca 1913, s. 6.

Z Sejmu Zjednoczenia Kapłanów Polskich w Ameryce, „Dziennik Chicagoski” nr 47, 25 lutego 1921, s. 5.

Z życia Polaków w Ameryce. Z Norwich, Conn., „Dziennik Chicagoski” nr 194, 21 sierpnia 1905, s. 2.

\section{PARAFIA NSPJ W NEW BRITAIN I JEJ DUSZPASTERZE NA ŁAMACH ,DZIENNIKA CHICAGOSKIEGO” W LATACH 1894-1920}

\section{Streszczenie}

Parafia nowobretańska miała charakter narodowy i personalny, liczyła około 7,5 tys. wiernych, i tak zaprezentowana została na łamach „Dziennika Chicagoskiego”. Jej pierwszy proboszcz, ks. Lucjan Bójnowski, pozostał na tym stanowisku 62 lata (1895-1957). W tym czasie zbudowano kościół drewniany, po 1902 r. murowany, a także szkołę i ochronkę, wydawano gazetę. Wokół tej parafii swoją działalność prowadziły różne towarzystwa religijne, kulturalne i narodowe mające na celu pogłębianie i podtrzymanie polskiej świadomości narodowej wśród emigrantów, więzi ze starym krajem, pogłębianie życia religijnego. Obok pomocy duchowej, uroczystych nabożeństw, parafia polska w New Britain dostarczyła do „błękitnej armii” wielu rekrutów, a także tysiące dolarów pomocy materialnej staremu krajowi. Do armii polskiej we Francji wstąpiło z tej parafii polskiej 290 ochotników. Łącznie do armii polskiej i amerykańskiej wstąpiło 965 Polaków. Z nich 123 oddało życie.

Ogromną rolę odegrała parafia polska przede wszystkim w sprawach odrodzenia poczucia narodowego i odrodzenia niepodległego Państwa Polskiego. Więź emigrantów polskich z Kościołem poza ojczystym krajem kształtowała poczucie tożsamości religijnej i narodowej.

Słowa kluczowe: Polacy w New Britain; ks. Lucjan Bójnowski; duszpasterze polscy; parafia polska; szkoła polska 


\section{SACRED HEART PARISH IN NEW BRITAIN AND ITS PASTORS IN “CHICAGO DAILY NEWS” IN THE YEARS 1894-1920}

\section{Summary}

The parish in New Britain had a national and personal character, it was a community of about 7.5 thousand believers. This is how it was presented in "Chicago Daily News." Its first parish priest, Fr. Lucjan Bójnowski, held this position for 62 years (1895-1957). At that time, a wooden church was built, after 1902 a brick one, and later a school and a nursery, the parish published a newspaper. Various religious, cultural and national societies were affiliated with the parish, and their aim was to maintain the Polish national consciousness among the emigrants, the ties with the old homeland and to deepen religious life. In addition to spiritual assistance and religious services, the Polish parish in New Britain provided the Blue Army with many recruits as well as thousands of dollars in material assistance to Poland. The Polish army in France was joined by 290 volunteers from that Polish parish. A total of 965 Poles joined the Polish and American armies; of these, 123 lost their lives.

The Polish parish played a huge role primarily in the matters of the rebirth of national feeling and the independent Polish State. The bond of Polish emigrants with the Church outside their homeland shaped the sense of religious and national identity.

Keywords: Poles in New Britain; Fr. Lucjan Bójnowski; Polish pastors; Polish parish; Polish school 